\title{
Further Reflections on the Iowa Black Suffrage Victory
}

\author{
HUbert H. WUbBeN
}

Having read Robert Dykstra's defense of the Iowa Republicans (Annals of Iowa 47 (Summer 1984), 430-450), I am better informed as to the forces behind their civil rights victory in 1865 . He rightly ascertains that I am somewhat skeptical about the depth of the commitment of many Iowa Republicans at that time to civil equality for blacks. And I do suggest that the character of the Democratic opposition was of some importance in making it easier for the party generally to "take the high road." But this has not led me to the stark conclusion that the Republicans "did a good thing ... for a bad reason," or to believe that their triumph at the 1865 convention was a "fluke," "an unaccountable political accident," or that their motives were "mysterious."

I do believe that, despite the prevalent racism among nearly all Iowans, the immediate circumstances, shaped as they were by changes taking place in the state from 1854 on, favored some implicit. Republican acceptance of black votes, and beyond that, an explicit endorsement if the no-compromise-against-principle minority stuck to its guns and took advantage of every opportunity which came its way. The presiding officer of the convention provided one such opportunity with his ruling that tabling Russell's explicit amendment to the resolutions committee report would require tabling the entire report. This forced the whole convention to deal with the issue, to "face up," to listen to its most powerful orators, Hiram Price, Henry O'Connor, and Enoch Eastman. Indeed, as Dykstra notes, this is the kind of situation described by Thomas Pettigrew in which committed minorities can persuade "conforming" majorities to take stands which they would normally not 
take. All things considered, it seems to me that the outcome was neither a fluke nor a foregone conclusion. Rather, it was one of several not too sharply divergent possibilities, although it was the one which would stimulate the most dissension.

As to my possibly being in the pessimistic rather than in the optimistic historiographical tradition regarding the prewar abolitionists and the postwar Radical Republicans, four things come to mind. They are not entirely of a piece, but they are all at least peripherally related to the point. My students over the last two decades have become well acquainted with all of them.

First, there is Lord Charnwood's singularly appropriate judgment that "the North would have been depraved had it not bred abolitionists." Second, if William Lloyd Garrison and Thaddeus Stevens had been fighting to free white slaves and to enhance the condition of white freedmen, statues honoring them would pose severe traffic hazards in the main streets of hundreds of American communities from coast to coast. Third, without passage of the 14th and 15th amendments to the United States Constitution, regardless of the mixed motives of some of their proponents, the racial history of this country, right up to the present, would be a much sadder and even nastier history than it has been.

Fourth, the late military historian, S. L. A. Marshall, once wrote about combat infantrymen, "Don't expect too much." Marshall was not condemning them. He simply knew something about the limits of human beings confronted with hard choices. He knew that when the going got tough, the tough usually did get going. But those who were less tough could not be expected to get going on their own. They would, however, respond to able, intelligent, forceful leadership, and do their part. The analogy is hardly exact, to be sure. Yet, to the extent that it is, the generality of Iowa Republicans were like them; they did their part.

A last point: I think Dykstra is correct in the last paragraph of his text when he says: "racial inequality remains the nation's most important unresolved problem"; in his admonition that we need all the examples we can get of successful, relevant political strategies to combat it; and in his suggestion that lowa's Republican leaders, from 1865 to 1880 , employed such strategies. 
Future historians will likely look back upon the 1980s as a decade in which powerful elements of the national leadership, following their own political imperatives, took steps which exacerbated that problem. Latter-day Hiram Prices and Edward Russells may have their work cut out for them. 
Copyright of Annals of Iowa is the property of State of Iowa, by \& through the State Historical Society of Iowa and its content may not be copied or emailed to multiple sites or posted to a listserv without the copyright holder's express written permission. However, users may print, download, or email articles for individual use. 